\title{
Predicting Yield Response to Nitrogen Fertilization on Northern Great Plains Rangelands
}

\author{
J. ROSS WIGHT AND E. BRUCE GODFREY
}

\begin{abstract}
Using a data base developed from range fertilization research results in the Northern Great Plains, yield-predicting equations for both fertilized and nonfertilized range $\left(r^{2}=0.83 ; n=194\right.$ and $r^{2} 0.88$; $\mathbf{n}=51$, respectively) were developed. Independent variables included combinations of monthly precipitation and average site yield for nonfertilized range and additional variables representing $\mathrm{N}$-rate, $\mathbf{N}$-sink effect, and $\mathrm{N}$-rate with precipitation interactions for the fertilized range. Average site yield provided an effective means of accounting for the wide range of inherent productivity among range sites. The results of this research indicated that, in the Northern Great Plains, yield response of native range to $\mathbf{N}$ fertilization can be reliably predicted using readily obtainable climatic and site data.
\end{abstract}

Approximately 295 million ha in the western United States and the Canadian Provinces is classified in rangeland ecosystems. Approximately one-half of this area is found in the Northern Great Plains and is represented by plant communities where nitrogen $(N)$ fertilization has been used to produce additional forage. Despite a demonstrated potential to significantly increase forage production, range fertilization is not a widely accepted practice. The primary reason for low acceptance is that climatic variability plus fluctuating fertilizer costs and livestock prices make range improvements, such as fertilization, a high risk alternative use of capital.

Range forage response to $\mathrm{N}$ fertilization varies widely and is primarily a function of precipitation or available soil water and the rate at which nitrogen (N-rate) is applied (Fig. 1). Increased yield of

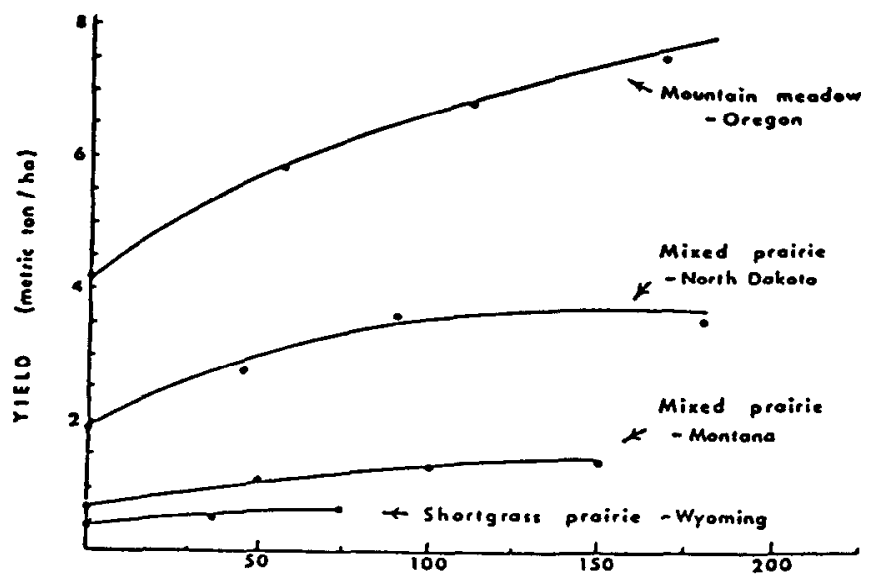

ANNUAL N-RATE (kg/ho)

Fig. 1. Herbage response to $N$ in 4 divergent grassland communities. (Wight 1980).

Authors are range scientist, USDA-ARS, Northwest Watershed Research Center, 270 South Orchard, Boise, lda. 83705 ; and associate professor of agricultural economics, Utah State University, UMC 35, Logan, Utah 84322.

Manuscript accepted August 13, 1984.
$100 \%$ or more following $\mathrm{N}$ fertilization is common. Yield response to $\mathrm{N}$ is also affected by site characteristics such as temperature, soil texture, inherent fertility, and vegetation composition. For specific sites, within a climatic zone, annual fluctuations in precipitation control response of range forage to $\mathrm{N}$ fertilization (Fig. 2). Not

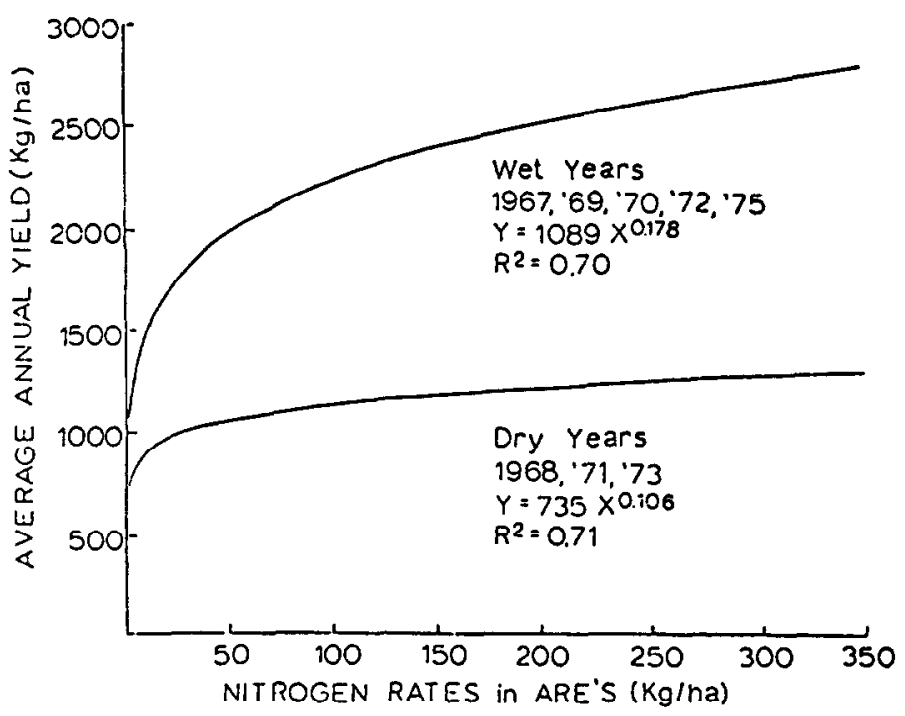

Fig. 2. The herbage yield- $N$ relationship as affected by annual climate (Wight and Black 1979).

only is the magnitude of the yield response to $\mathrm{N}$ greater with increased precipitation but the relationship between yield and $\mathrm{N}$-rate becomes linear over a wider range of $\mathrm{N}$-rates.

There have been numerous attempts to relate herbage production of nonfertilized range to environmental factors such as precipitation, soil, water, and pan evaporation. Recently, emphasis has bcen on the use of water balance, climate-type models to calculate evapotranspiration as an index to plant growth within native ecosystems (Wight and Hanks 1981). Attempts to relate yield response to fertilization on rangelands have been limited. Smika et al. (1965), working in North Dakota, demonstrated that yield response to $\mathrm{N}$ increased in a quadratic relationship as available water increased. They were able to calculate a regression equation for each $\mathrm{N}$-rate studied, but the limited quantity of data available did not allow them to estimate regression equations that were reliable predictors of forage production to fertilization.

Working in the same geographical area as Smika et al. (1965), Power and Alessi (1970) found that up to $65 \%$ of crested wheatgrass (Agropyron desertorum) yield could be accounted for by the May precipitation and, with adequate $\mathbf{N}$ fertilization, about 350 additional $\mathrm{kg}$ dry matter/ha could be expected for each centimeter of May precipitation. At all levels of fertilization studied, May precipitation provided the best index of yield.

In Canada, Johnston et al. (1969) studied the relationships between yield responses to range fertilization and precipitation, evaporation, and soil water. Using stepwise regression analyses, they found that fall soil water, May-September evaporation, and 
Table 1. Data sets used in regression analyses.

\begin{tabular}{|c|c|c|c|c|c|}
\hline Location & $\begin{array}{l}\text { Number of observations } \\
\text { (n) }\end{array}$ & Soil texture & $\begin{array}{l}\text { Average site yield } \\
(\mathrm{kg} / \mathrm{ha})^{\prime}\end{array}$ & $\begin{array}{c}\text { Average annual } \\
\text { precipitation (mm) }\end{array}$ & Reference \\
\hline Mandan & 46 & Silt-Loam & $\begin{array}{l}1901 \\
(289)\end{array}$ & $\begin{array}{l}403 \\
(83)\end{array}$ & Lorenz \& Rogler (1972) \\
\hline Havre & 47 & Loam & $\begin{array}{r}594 \\
(222)\end{array}$ & $\begin{array}{l}281 \\
(65)\end{array}$ & Houlton (1975) \\
\hline Sidney & 58 & Sandy-Loam & $\begin{array}{r}878 \\
(549)\end{array}$ & $\begin{array}{l}349 \\
(86)\end{array}$ & Wight \& Black (1979) \\
\hline Ekalaka & 28 & Clay & $\begin{array}{r}384 \\
(226)\end{array}$ & $\begin{array}{l}370 \\
(83)\end{array}$ & Wight, Unpub. data \\
\hline Ekalaka & 15 & Clay & $\begin{array}{l}157 \\
(29)\end{array}$ & $\begin{array}{l}370 \\
(83)\end{array}$ & Wight, Unpub. data \\
\hline
\end{tabular}

'Long-term averages. Numbers in parentheses represent the standard deviation.

May-June precipitation were significant and accounted for $95 \%$ of the variation in yield on check plots. On $\mathrm{N}$-fertilized plots, only June precipitation and May-September evaporation were significant, accounting for $71 \%$ of the yield variation. Fertilizer rate was not a variable, and no attempt was made to determine the effects of the different range sites included in the study.

In Montana, Burt et al. (1971) developed a model to predict hay yields of crested wheatgrass ( $A$. cristatum) based on the plantavailable soil $\mathrm{N}$ and seasonal precipitation, where soil $\mathrm{N}$ is the sum of the $\mathrm{N}$ application and carry-over soil $\mathrm{N}$. A distinctive feature of this model is the carry-over (Stauber et al. 1975) soil $\mathrm{N}$ which was calculated from previous $\mathrm{N}$ applications and yields.

The reported research has generally not included fertilizer rates and/or site characteristics as variables in their predictive models. As a result, these equations have limited application for range sites other than where the research was conducted. The study report herein utilizes the results of several studies in various areas within the Northern Great Plains to quantify the relationships between range forage response to the application of $\mathrm{N}$ as well as climatic and site variables. The estimated relationships are used to develop a predictive model as a tool to enhance range fertilization decisions.

\section{Methods}

A data base was developed from published and unpublished range fertilization research and results from several research locations in the Northern Great Plains that represented $S$ distinct range sites (Table 1). Variables considered included yield, N-rate, monthly precipitation, and the long-term average yield of the study site (site factor). All yield responses are expressed as $\mathrm{kg} / \mathrm{ha}$ on an oven-dry, ground-level basis. A N-sink factor was calculated to account for the "sink" effect described by Wight (1976) that was derived from the results of a study by Power (1972).

To develop a data base with a wide range of $\mathrm{N}$-rates, it was necessary to utilize the concept of annual rate equivalents (ARE) as described by Wight (1976) and Wight and Black (1979), wherein, a single application of $\mathrm{N}$ could be considered over a period of several years with a different $\mathrm{N}$-rate or ARE for each year. For example, the ARE of a single application of $300 \mathrm{~kg} \mathrm{~N} /$ ha would be respectively 300,150 , and $100 \mathrm{~kg} /$ ha for the year of application, and the first and second year following application. Previous research results indicated that ARE $N$ treatments produce yield responses similar to equivalent annual $N$ treatments (Wight 1976, Wight and Black 1979). In this study, ARE's were used interchangeably with equivalent annual rates.

Long-term average site yields were derived by estimating a linear regression equation that included precipitation and site variables (unpublished data available from senior author). In actual practice, the site factor could be estimated from sources such as historical data or yield values assigned by the Soil Conservation Service range site classifications.

Response to $\mathrm{N}$ was determined both in terms of yield increase (fertilized plot minus check plot) and N-use efficiency (NUE). NUE as described by Wight (1976) is the additional units of forage produced per unit of $\mathrm{N}$ applied, and provides an index to compare yield response to $\mathrm{N}$ rate among sites and years.

\section{Results and Discussions}

Before performing regression analyses to quantify relationships between yield response to $\mathrm{N}$-rate, precipitation, and site variables, an additional factor was developed to account for the $\mathrm{N}$-sink effect. Using data from Power and Alessi (1971), it was found that 180 to $270 \mathrm{~kg} \mathrm{~N} / \mathrm{ha}$ had to be applied to a site with an average annual yield

Table 2. Regression coefficient, standard errors, computed t-values, and the standard error of estimate for equation [2].

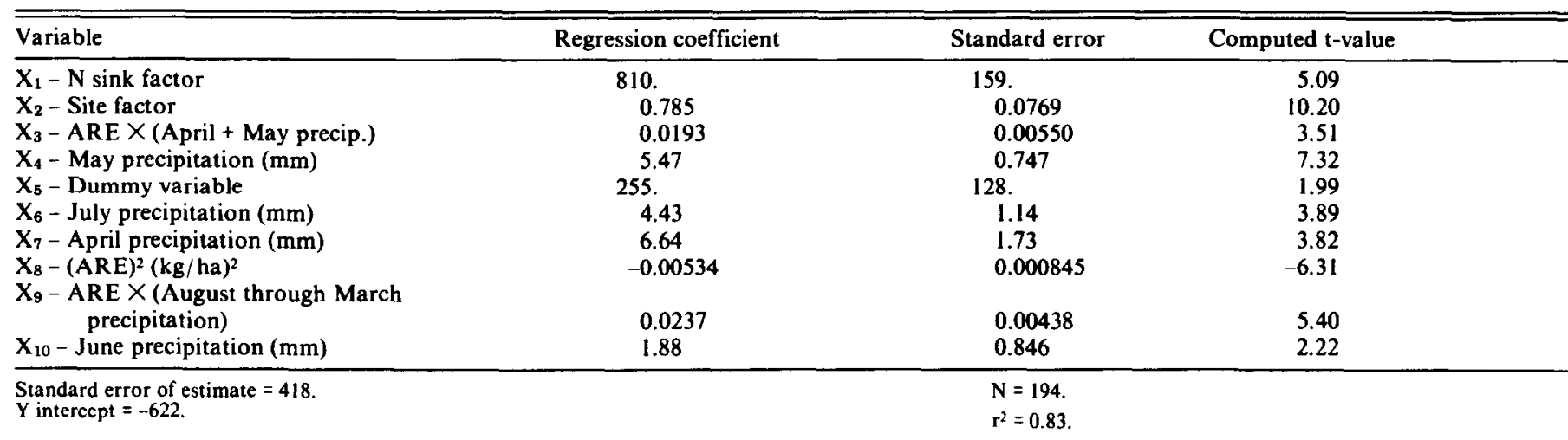


of $1,900 \mathrm{~kg} /$ ha to obtain maximum yield response. Initial $\mathrm{N}$-rates above $270 \mathrm{~kg} \mathrm{~N} /$ ha produced little additional yield. The data also indicated that proportionally smaller initial $\mathrm{N}$ applications resulted in smaller yields. However, once the $\mathrm{N}$-sink had been satisfied, annual $\mathrm{N}$-rates of less than $90 \mathrm{~kg} / \mathrm{ha}$ resulted in maximum production levels. The amount of $\mathbf{N}$ needed to satisfy the $\mathrm{N}$-sink will probably vary with site, precipitation, and the amount of root material present. It was assumed that the magnitude of the $\mathrm{N}$-sink was proportional to the average site yield with a maximum value of $270 \mathrm{~kg} \mathrm{~N} /$ ha on a site with an average annual yield of $1,900 \mathrm{~kg} / \mathrm{ha}$ or greater. The $\mathrm{N}$-sink factor was determined as the portion of the $\mathrm{N}$-sink that had been satisfied with the application of $\mathrm{N}$. This sink factor ( $\mathrm{N}$-sink) was calculated using equation [1],

$$
\mathrm{N} \text {-sink }=\mathrm{TN} \div(270 \times \mathrm{SF} / 1900) \text {, }
$$

where TN is the total $\mathrm{N}$ applied and SF is the site factor (average site yield). All resultant $\mathrm{N}$-sink factor values greater than 1.0 were set equal to 1.0. Until $\mathrm{N}$ cycling on rangeland is better understood, this factor provides a means of accounting for the $\mathrm{N}$-sink effect in yield predicting equations. Although the $\mathrm{N}$-sink factor implies permanency, in practical use the TN component can be reset to zero anytime a significant tie-up of applied $\mathbf{N}$ becomes evident.

Range forage response to $\mathrm{N}$-fertilization is often greater the first year than during following years when equivalent growing conditions exist. Lorenz and Rogler (1967) attributed this to greater water use from the stimulation of root systems by $\mathbf{N}$ fertilization of previously nonfertilized sites. Under semiarid conditions, this is basically a one-time water source, because deeper portions of range soil profiles are only occasionally recharged. To account for this additional forage response, a dummy variable was used with an assigned value of 1 for the first year following fertilization and 0 for subsequent years.

Several regression equations were estimated, all based on the data sets shown in (Table 1). The dependent variable (yield) was regressed against the following independent variables: $N$-rate, site factor, N-sink factor, and various combinations of monthly precipitation where precipitation was measured in millimeters. Equation [2] (Table 2) was selected as best for quantifying the relationships between the dependent and independent variables while being biologically acceptable.

$$
\mathrm{Y}_{1}=\beta_{0}+\sum_{\mathrm{i}=1}^{10} \beta_{\mathrm{i}} \mathrm{X}_{\mathrm{i}}=\mathrm{e}_{1} .
$$

Other alternative equations (e.g., Cobb-Douglas type, logarithmic) were formed, but these equations were judged to be inferior to equation [2]. The primary reason for rejecting these alternative equations was the examination of the residual plots and concepts set forth in Draper \& Smith (1966) and Kennedy (1979). The residual plots indicated that a cubic term could be added ( $A R E^{3}$ ), but this variable was not statistically significant for these data. The estimated regression cocfficients (Table 2) all have the expected signs and are statistically different from zero at probability levels greater than $95 \%$. In addition, there was little evidence that the classic assumptions used in regression analysis were violated (Kennedy 1979).

Several characteristics of equation [2] ought to be noted. First, the magnitude of the estimated coefficients $\left(\hat{\beta}_{i}\right)$ for each of the periods of precipitation had the expected orders of magnitude. Secondly, precipitation-fertilizer interactions $\left(\hat{\beta}_{3}\right.$ and $\left.\hat{\beta}_{9}\right)$ indicated a strong complementary association between precipitation and the application of $\mathrm{N}$. Thus, in years of less than normal precipitation, the application of $\mathbf{N}$ would yield less forage than in years of above normal precipitation. Third, if the first derivative of equation [2] with respect to ARE is taken,

$$
\begin{aligned}
& \frac{\partial \mathrm{Y}_{1}}{\partial \mathrm{ARE}}=\beta_{3}(\text { April }+ \text { May precipitation })+\beta_{8} \mathrm{ARE} \\
& +\beta_{9} \text { (August }- \text { May precipitation) }
\end{aligned}
$$

and is set equal to zero with average levels of precipitation, equation [2] would be maximized when about $485 \mathrm{~kg} /$ ha of $\mathrm{N}$ is applied. This would imply that nearly $2,500 \mathrm{~kg} / \mathrm{ha}$ of forage would be produced if this level of $\mathbf{N}$ was applied. It should be noted, however, that this level would increase if greater than average precipitation was available during the August through May period.

Any economic evaluation of practices, such a fertilization, must be based on the returns with fertilization vs. the returns without fertilization. In an effort to obtain this data, equation [3] was estimated using only check-plot data (Table 3).

$$
\mathrm{Y}_{2}=\mathrm{d}_{0}+\mathrm{d}_{1} \mathrm{U}_{1}+\mathrm{d}_{2} \mathrm{U}_{2}+\mathrm{d}_{3} \mathrm{U}_{3}+\mathrm{d}_{4} \mathrm{U}_{4}+\mathrm{d}_{5} \mathrm{U}_{5}+\mathrm{d}_{6} \mathrm{U}_{6}+\mathrm{e}_{2}
$$

Each of the estimated regression coefficients (Table 3 ) was statistically different from zero at levels probability in excess of $85 \%$ and

Table 3. Regression coefficients, standard errors, computed t-values, and the standard error of estimates for equation [3].

\begin{tabular}{lccc}
\hline \hline Variable & $\begin{array}{c}\text { Regression } \\
\text { coefficient }\end{array}$ & $\begin{array}{c}\text { Standard } \\
\text { error }\end{array}$ & $\begin{array}{c}\text { Computed } \\
\text { t-value }\end{array}$ \\
\hline $\mathrm{U}_{1}$ - Site factor & 0.855 & 0.0658 & 13.00 \\
$\mathrm{U}_{2}$ - July precipitation $(\mathrm{mm})$ & 3.26 & 1.21 & 2.69 \\
$\mathrm{U}_{3}$ - May precipitation $(\mathrm{mm})$ & 2.73 & 0.0832 & 3.28 \\
$\mathrm{U}_{4}-$ April precipitation $(\mathrm{mm})$ & 5.70 & 1.87 & 3.04 \\
$\mathrm{U}_{5}-$ August through March & & & \\
$\quad$ Precipitation (mm) & 1.20 & 0.774 & 1.55 \\
$\mathrm{U}_{6}-$ June precipitation $(\mathrm{mm})$ & 1.42 & 0.965 & 1.47 \\
\hline
\end{tabular}

Standard error of estimate -239 .

$Y$ intercept $=-638$.

$\mathrm{n}=51$.

$r^{2}=-0.88$.

all had the expected signs. The site factor $\left(U_{1}\right)$ in equation [3] accounted for a large portion of the variation in yield indicating that, within a given climatic zone, range site has a major influence on yield. This can be observed in the average yield of the two Ekalaka sites differed by more than $100 \%$ although both received the same amount of precipitation (Table 1).

Equations [2] and [3] were tested for goodness of fit using data from Miles City, Mont., and Mandan, N. Dak., which were not used to estimate equations [2] or [3]. These data represent a wide range of productivity levels within the Northern Great Plains. For fertilized and nonfertilized range, equations [2] and [3] performed reasonably (Fig. 3) well with $r^{2}$ values of $0.84 ; n=25$ and $0.97 ; n=$ 10 , respectively, for the fit of the predicted values to actual observations. These results suggested that the above regression equations fit one of the major criteria, predictability, for accepting a model.

Equations [2] and [3] provide a means of simulating the effects of climatic variations, N-rates, and fertilizer schemes for various range sites. This is illustrated with a computer model that was developed utilizing equations [2] and [3] to predict the response of $\mathbf{N}$ fertilization in terms of NUE and forage production. Inputs include the fertilization scheme (rates and years applied), average yield of the site to which the fertilizer will be applied, and expected precipitation for August through March, April, May, June, and July. For spring applied fertilizer, the August through March precipitation would be known and the April, May, June, and July values could be estimated from long-term averages or determined from rainfall probability tables. Examples of the model's output (Table 4) show the $\mathrm{N}$-sink effect. With annual applications of 40 $\mathrm{kg} / \mathrm{ha}$, it is not until the 7th year that NUE and yield increase reach a maximum. A comparison of total yields for the $40 \mathrm{~kg} \mathrm{~N} / \mathrm{ha}$ annual treatment and the $120 \mathrm{~kg} \mathrm{~N} /$ ha triennial treatment shows the advantage of using an initial $\mathbf{N}$ application that is sufficiently large to at least partially overcome the $\mathrm{N}$-sink effect. The cumulative $\mathrm{N}$ applicd after 9 years was $360 \mathrm{~kg} / \mathrm{ha}$ for both fertilizer schemes, but the cumulative yield increases were 4,672 and 5,644 for the $40 \mathrm{~kg} \mathrm{~N} /$ ha annual applications and the $120 \mathrm{~kg} \mathrm{~N} / \mathrm{ha}$ triennial application, respectively. The $120 \mathrm{~kg} \mathrm{~N} /$ ha triennial application increased total yield response $972 \mathrm{~kg} / \mathrm{ha}$ and increased 


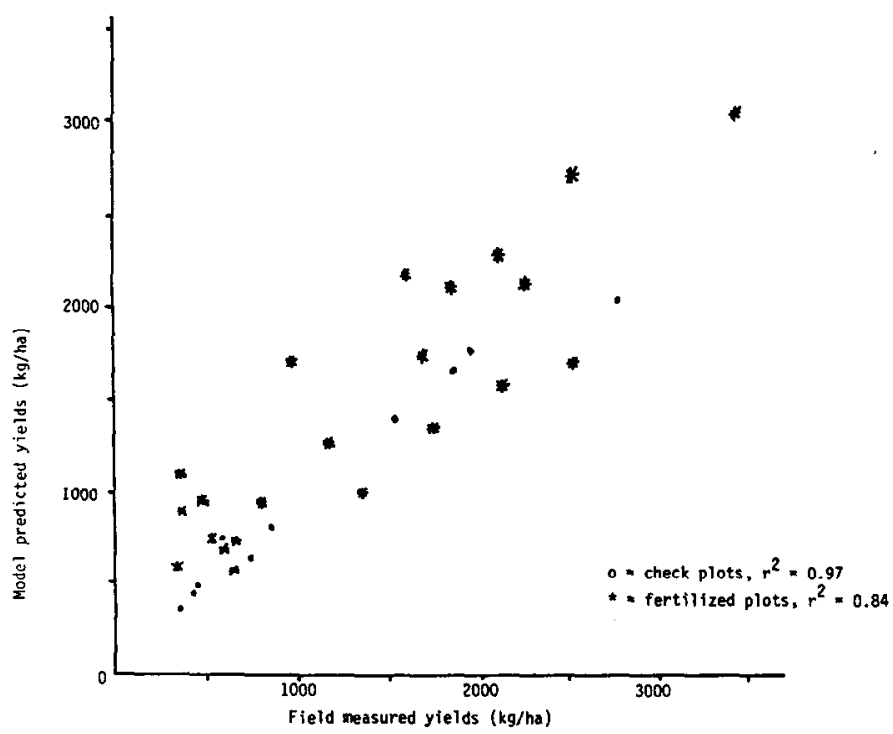

Fig. 3. Comparison of model-predicted and field-measured yield:for range sites in Miles City, Mont., and Mandan, N. Dak.

the overall NUE from 13.0 to 15.7 as compared to the $40 \mathrm{~kg} \mathrm{~N} / \mathrm{ha}$ annual application.

\section{Conclusions}

The above model indicates that these equations can be used to predict yield response to $\mathrm{N}$ using readily available input variables. Its major application should be to enhance range fertilization recommendations and remove some of the associated financial risks. The model should also serve as a valuable component of more complex simulation or optimization models which take into account such items as individual ranch budgets, fertilizer costs, and livestock values.

Table 4. A comparison of two fertilization schemes over a 9-year period using long-term precipitation and the site factor for Sidney, MT, and the predicting equations in Tables 2 and 3.

\begin{tabular}{|c|c|c|c|c|c|c|c|}
\hline \multicolumn{8}{|c|}{ Scheme 1} \\
\hline Year & $\begin{array}{c}\mathrm{N} \\
\text { applied }\end{array}$ & ARE & $\begin{array}{c}\text { Total } \\
\mathbf{N} \\
\text { applied }\end{array}$ & $\begin{array}{c}\text { Yield } \\
\text { of } \\
\text { check }\end{array}$ & $\begin{array}{c}\text { Total } \\
\text { Annual } \\
\text { yield }\end{array}$ & Increase & NUE \\
\hline $\begin{array}{c}1 \\
2 \\
3 \\
4 \\
5 \\
6 \\
7 \\
8 \\
9 \\
\text { Total }\end{array}$ & $\begin{array}{r}40 \\
40 \\
40 \\
40 \\
40 \\
40 \\
40 \\
40 \\
40 \\
360\end{array}$ & $\begin{array}{l}40 \\
40 \\
40 \\
40 \\
40 \\
40 \\
40 \\
40 \\
40 \\
-\end{array}$ & $\begin{array}{c}40 \\
80 \\
120 \\
160 \\
200 \\
240 \\
280 \\
320 \\
360 \\
\text { Schem }\end{array}$ & $\begin{array}{l}859 \\
859 \\
859 \\
859 \\
859 \\
859 \\
859 \\
859 \\
859 \\
-\end{array}$ & $\begin{array}{r}1406 \\
1206 \\
1262 \\
1317 \\
1373 \\
1428 \\
1470 \\
1470 \\
1470 \\
12402\end{array}$ & $\begin{array}{r}547 \\
348 \\
403 \\
456 \\
514 \\
569 \\
611 \\
611 \\
611 \\
4672\end{array}$ & $\begin{array}{r}13.7 \\
8.7 \\
10.1 \\
11.5 \\
12.8 \\
14.2 \\
15.3 \\
15.3 \\
15.3 \\
-\end{array}$ \\
\hline Year & $\begin{array}{c}\mathrm{N} \\
\text { applied }\end{array}$ & ARE & $\begin{array}{c}\text { Total } \\
\mathbf{N} \\
\text { applied }\end{array}$ & $\begin{array}{c}\text { Yield } \\
\text { of } \\
\text { check }\end{array}$ & $\begin{array}{c}\text { Total } \\
\text { Annual } \\
\text { yield }\end{array}$ & Increase & NUE \\
\hline $\begin{array}{c}1 \\
2 \\
3 \\
4 \\
5 \\
6 \\
7 \\
8 \\
9 \\
\text { Total }\end{array}$ & $\begin{array}{r}120 \\
0 \\
0 \\
120 \\
0 \\
0 \\
120 \\
0 \\
0 \\
360\end{array}$ & $\begin{array}{r}120 \\
60 \\
40 \\
60 \\
48 \\
40 \\
51 \\
45 \\
40 \\
-\end{array}$ & $\begin{array}{l}120 \\
120 \\
120 \\
240 \\
240 \\
240 \\
360 \\
360 \\
360 \\
-\end{array}$ & $\begin{array}{l}859 \\
859 \\
859 \\
859 \\
859 \\
859 \\
859 \\
859 \\
859 \\
-\end{array}$ & $\begin{array}{r}1858 \\
1354 \\
1262 \\
1520 \\
1465 \\
1428 \\
1523 \\
1493 \\
1470 \\
13373\end{array}$ & $\begin{array}{r}1000 \\
495 \\
403 \\
661 \\
607 \\
569 \\
664 \\
634 \\
611 \\
5644\end{array}$ & $\begin{array}{r}8.3 \\
8.2 \\
10.1 \\
11.0 \\
12.6 \\
14.2 \\
12.9 \\
14.1 \\
15.3 \\
-\end{array}$ \\
\hline
\end{tabular}

Burt, Oscar R., M.S. Stauber, and Ray Choriki. 1971. Economic use of nitrogen on crested wheatgrass in central Montana. In: Proc., Twentysecond Annu. Fertilizer Conf. Pacific Northwest, Bozeman, Mont., July 12-15, 1971.

Draper, N.R., and H. Smith. 1966. Applied regression analysis. John R. Wiley and Sons, Inc., New York.

Houlton, Harold A.R. 1975. Range vegetation response to nitrogen fertilization in North Central Montana Agr. Exp. Sta. Res. Rep. 70. Montana State Univ., Bozeman.

Johnston, A., S. Smoliak, A.D. Smith, and L.E. Lutwick. 1969. Seasonal precipitation, evaporation, soil moisture, and yield of fertilized range vegetation. Can. J. Plant Sci. 49:123-128.

Kennedy, Peter. 1979. A guide to econometrics. The MIT Press. Cambridge.

Lorenz, R.J., and G.A. Rogler. 1967. Grazing fertilization affect root development of range grasses. J. Range Manage. 20:129-132.

Lorenz, Russell J., and George A. Rogler. 1972. Forage production and botanical composition of mixed prairie as influenced by nitrogen and phosphorus fertilization. Agron. J. 64:244-249.

Power, J.F., and J. Alessi. 1970. Effects of nitrogen source and phosphorus on crested wheatgrass growth and water use. J. Range Manage. 23:175-178.

Power, J.F., and J. Alessi. 1971. Nitrogen fertilization of semiarid grasslands: Plant growth and soil mineral N levels. Agron J. 63:177-180.

Power, J.F. 1972. Fate of fertilizer nitrogen applied to a Northern Great Plains ecosystem. J. Range Manage. 25:367-371.

Smika, D.E., H.J. Haas, and J.F. Power. 1965. Effects of moisture and nitrogen fertilizer on growth and water use by native grass. Agron. J. 57:483-486.

Stauber, M.S., Oscar R. Burt, and Fred Linse. 1975. An economic evaluation of nitrogen fertilization of grasses when carry-over is significant. American J. Agr. Econ. 463-472.

Wight, J. Ross. 1976. Range fertilization in the Northern Great Plains. J. Range Manage. 29:180-185.

Wight, J. Ross. 1980. Range fertilization: The role of phosphorus. Better Crops with Plant Food. Summer 1980. 65:24-26.

Wight, J. Ross, and A.L. Black. 1979. Range fertilization: Plant response and water use. J. Range Manage. 32:345-349.

Wight, J. Ross, and R.J. Hanks. 1981. Predicting range herbage production with a water-balance, climate model. J. Range Manage. 34:307-31 I. 